UDC 616.441.-006.6-092.9:615.252

doi: https://doi.org/10.15407/ubj88.05.090

\title{
PROTEIN KINASE Akt ACTIVITY IN HUMAN THYROID TUMORS
}

\author{
B. B. GUDA, V. V. PUSHKAREV, O. V. ZHURAVEL, A. Ye. KOVALENKO, \\ V. M. PUSHKAREV, Y. M. TARASCHENKO, M. D. TRONKO
}

State Institution V. P. Komisarenko Institute of Endocrinology and Metabolism, National Academy of Medical Sciences of Ukraine, Kyiv;

e-mail: pushkarev.vm@gmail.com

We studied the expression and activation of the main effector protein kinase of phosphatidylinositol3-kinase cascade (PI3K) - Akt in conventionally normal tissues, benign and highly differentiated (with and without metastases) human thyroid tumors. There was a difference in the Akt1 amount in tumor tissue compared with normal tissue in papillary carcinomas and tissue of multinodular goiter. Akt expression both in tumor and conventionally normal tissues of follicular adenoma was significantly lower than in follicular carcinoma. The lowest level of Akt expression was observed in tissues of multinodular goiter. Total activity of all three isoforms of Akt1/2/3 was lower in tumors compared to conventionally normal tissue. Thus, Akt activity (according to Thr308 phosphorylation) is not associated with proliferative processes in the tumor tissue of the thyroid. Apoptosis level detected in these tissues was not associated with the protein kinase activity either. Possible mechanisms of signaling cascade PI3K/Akt inhibition in thyroid tumors are discussed.

Key word s: thyroid gland, benign and malignant tumors, signaling cascade PI3K/Akt.

$\mathrm{P}$ roliferative processes in tumor cells are controlled by two main pathways: PI3K/Akt and mitogen-activated protein kinases (MAPK). The latter actually regulates cell division. PI3K/Akt prepares a cell for division.

Akt, also known as protein kinase B (PKB), belongs to a family that combines protein kinases $\mathrm{C}$, cAMP-dependent and cGMP-dependent kinases. The gene encoding Akt was identified as a part of the genome of the murine leukemia transforming virus (v-akt murine thymoma viral oncogene homolog) in 1977 and classified as an oncogene. The man's Akt family includes three evolutionarily conserved isoforms: Akt1 (including 3 splicing variants), Akt2 and Akt3 (2 splicing variants). Akt isoforms play a key role in various cellular processes including apoptosis, growth, proliferation, polarity, migration, DNA repair, glucose transport, metabolism, skeletal muscle and cardiomyocytes contractility, angiogenesis and self-renewal of stem cells. Dysregulation of Akt activity is associated with malignant transformation of cells, cardiovascular disease, type 2 diabetes, muscular hypotrophy and neurodegenerative diseases [1].
Signaling cascade PI3K/PDK/Akt is involved in the regulation of protein synthesis and cell energy supply, i.e. in preparation of a cell for mitosis. Moreover, this signaling cascade inhibits apoptosis, promotes the survival of tumor cells and is activated in many types of cancer [2]. Furthermore, mutations and amplification of individual components of PI3K/ Akt pathway causes malignant transformation of cells of different origins, including thyroid [3], while inhibiting the cascade with specific inhibitors enhances the therapeutic effect of anticancer drugs [4]. Akt activity is mainly regulated through phosphorylation of Thr308 and Ser473 amino acid residues by PDK1 and mTORC 2 kinases, respectively.

A significant increase of proliferating cell nuclear antigen (PCNA) in thyroid tumors, especially in aggressive tumors with metastases, indicating a substantial increase of proliferative processes was demonstrated previously [5]. The aim of our work was to ascertain the expression and activation peculiarities of Akt as the phosphatidylinositol-3-kinase cascade main effector kinase, and the apoptosis level in human thyroid normal tissues, benign and malignant tumors. 


\section{Materials and Methods}

The study was conducted on patient's postoperative material obtained in the surgical department of the Institute. All patients signed informed consent before surgery to the use of the postoperative material for research. As conventionally normal tissue unaltered thyroid tissue was taken, which by morphological criteria did not differ from normal. After removal thyroid tissue was immediately placed on ice and quickly frozen at $-80^{\circ} \mathrm{C}$.

To determine Akt1 and phospho-Akt1/2/3 (phospho-Thr308) in thyroid homogenates Abcam (UK) ELISA kits ab176658 were used. To determine cleaved PARP ELISA kits ab119690 of the same company were used. Measurements were performed on microplate reader of Bio-tek Instruments (USA) at a wavelength of $450 \mathrm{~nm}$. The study was performed in 3 replications. The number of transformed tissue samples was 3 (follicular carcinoma and multinodular goiter) and 6 (follicular adenoma, encapsulated tumor papillary carcinoma and non-encapsulated tumor papillary carcinoma). Tissue was homogenized in a Retsch TissueLyser II homogenizer (Germany) in a special kit provided buffer that prevents proteins degradation and dephosphorylation. Protein concentration in the lysate was determined with a Novagen (USA) BCA protein assay kit.

The experiments results were presented as $M \pm m ; n=3-6$. $t$-Student test was used to compare these data groups.

\section{Results and Discussion}

Table 1 shows that there is a fairly high level of Akt expression in all studied tissues, both normal and tumoral. The content of Aktl in conventionally normal and tumor tissue of follicular carcinoma (FTC) and follicular adenoma (FA) did not differ significantly, in contrast to papillary carcinomas (PTC) and goiter (MNG), where the level of kinase in tumor tissue exceeded the one in conventionally normal tissue almost 2 times (Table 1). It should be noted that Akt expression both in tumor and conventionally normal tissues of FA was significantly lower than in FTC tissues. The lowest level of Akt expression we observed in multinodular goiter (Table 1).

It is known that disruption of the PI3K/Akt pathway as a result of Ras, PTEN, PIK3CA genes mutations and amplifications is one of the reasons for thyroid papillary carcinoma genesis [3], although $R E T$ gene rearrangements and mutations in genes
Table 1. Akt1 expression in different types of thyroid tumors

\begin{tabular}{l|c|c}
\hline & $\begin{array}{c}\text { Conventionally } \\
\text { normal tissue } \\
(\text { OD) }\end{array}$ & $\begin{array}{c}\text { Transformed } \\
\text { tissue (OD) }\end{array}$ \\
\hline FTC & $0.360 \pm 0.042$ & $0.335 \pm 0.048$ \\
FA & $0.221 \pm 0.032$ & $0.182 \pm 0.073$ \\
iPTC & $0.198 \pm 0.013$ & $0.327 \pm 0.072^{*}$ \\
nPTC & $0.228 \pm 0.004$ & $0.416 \pm 0.146^{*}$ \\
MNG & $0.092 \pm 0.006$ & $0.159 \pm 0.026^{*}$ \\
\hline
\end{tabular}

Note. In the table and further figures: FTC - follicular carcinoma, FA - follicular adenoma, iPTC - papillary carcinoma (encapsulated tumors), nPTC - papillary carcinoma (non-encapsulated tumors), $\mathrm{MNG}$ - multinodular goiter. OD - optical density at $450 \mathrm{~nm}$ per $\mathrm{mg}$ of protein, $M \pm m ; n=3$ (FTC, MNG) and 6 (FA, iPTC, nPTC); $*$ difference between conventionally normal and tumor tissues is significant, $P<0.05$

encoding the protein kinases of MAPK cascade are more typical of this type of cancer. It is harder to explain the lack of difference in the Aktl expression in follicular carcinomas compared to the normal tissue, since PI3K catalytic subunit - PIK3CA - gene activating amplification and mutations are found more often in the FTC $-10-15$ and $24 \%$ of cases, respectively [3].

A different picture was observed regarding Akt1/2/3 activation (Fig. 1). The level of phosphoAkt in conventionally normal tissue of all tumors was considerably higher (almost 8.5 times for the FTC and more than 18 times for nPTC) than in tumor tissue, and was practically absent in encapsulated papillary carcinomas (Fig. 1). Thus, contrary to expectations, the Akt activity in papillary and follicular carcinomas and follicular adenomas was either absent or substantially suppressed, indicating a lack of link between the protein kinase activation by the PI3K/PDK-1 pathway (phosphorylation of Thr308 residue) and enhanced proliferative processes in thyroid tumors, which we observed in the same samples previously [5].

It was established that in tumor tissues Akt suppresses apoptosis by inhibiting caspase-9, proapoptotic protein Bad, FKHR and FOHO transcription factors; affects the activity of cell cycle inhibitors $\mathrm{p} 21, \mathrm{p} 27$, Gsk-3 3 protein kinase and the state of $\mathrm{Mdm} 2$ - a tumor suppressor $\mathrm{p} 53$ regulator - that generally causes cell cycle dysregulation and un- 


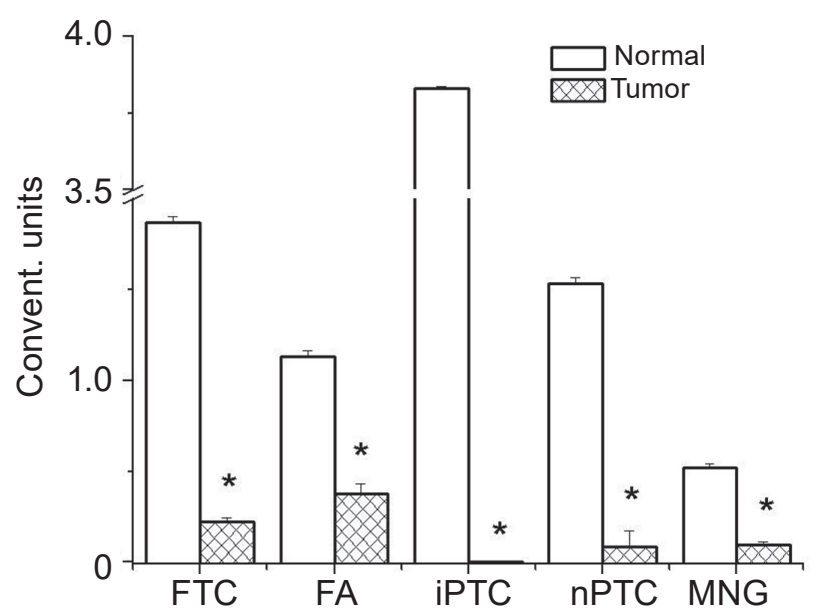

Fig. 1. Akt1/2/3 activity in different types of thyroid tumors in conventional units. Data normalized with regard to total Akt amount. *Difference between conventionally normal and tumor tissues is significant, $P<0.05$

controlled proliferation; activates IKK and NF- $\kappa \mathrm{B}-$ dependent signaling pathway, promoting tumor cell survival, angiogenesis and metastasis formation; increases tumor growth through mTOR activation $[2,6]$. Furthermore, excessive Akt activation leads to tumor resistance to radiation and chemotherapy $[7,8]$. Therefore, we determined the apoptosis level by cleaved PARP larger fragment ( $89 \mathrm{kDa})$ amount, which is characteristic for apoptotic responses. Fig. 2 shows that the PARP fragment amount in papillary carcinomas and goiter doesn't differ significantly from conventionally normal tissue. In follicular carcinoma samples cleaved PARP amount is higher, and in follicular adenoma samples it is lower compared to conventionally normal thyroid tissue.

It was expected that increased Akt activity/content would lead to apoptosis intensity reduction and vice versa. However, increased amount of cleaved PARP against reduced kinase activity was observed only in follicular adenoma tissue (Fig. 2). Thus, Akt content and activity are not related to the apoptosis level in the studied tissues.

The fact of considerable kinase activity inhibition in thyroid carcinomas deserves special attention. A possible explanation for this are data indicating that Akt might participate in the replicative senescence of normal and tumor cells [9-12], a phenomenon, that along with apoptosis inhibits tumor growth. In addition, Akt can stimulate apoptosis [13] and inhibit the breast cancer cells migration [14].

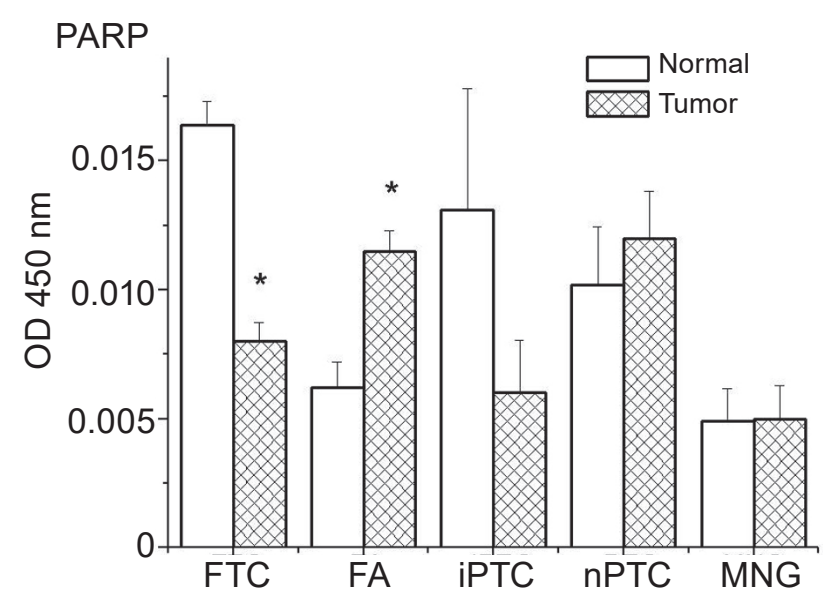

Fig. 2. Cleaved PARP (89 kDa) amount in different types of thyroid tumors. *Difference between conventionally normal and tumor tissues is significant, $P<0.05$

Cell cycle regulator (inhibitor of cyclin-dependent kinases) $\mathrm{p} 21^{\mathrm{WAF} 1}$ is phosphorylated only by Akt1, that negatively regulates the cell cycle and proliferation [14]. Thus, under certain conditions Akt may show anti-proliferative and cancerostatic properties. This phenomenon was first demonstrated regarding MAPK and was named oncogene toxicity. It was shown that although Ras and Raf oncogenes are often involved in malignant transformation of thyroid cells, constitutive activation of this cascade in tumor tissues leads to growth arrest and senescence in many cases [15-18]. For example activated Ras or c-Raf-1 cause cell growth arrest by producing and secreting autocrine/paracrine factor LIF (leukemia inhibiting factor) in human medullary thyroid carcinoma cells [15]. Sustained activation of Raf/ MEK/ERK signaling pathway causes growth arrest, accompanied by corresponding cell cycle regulators states changes ( $\mathrm{pRB}$ dephosphorylation, E2F1 down-regulation and $\mathrm{p} 21^{\mathrm{WAF} 1}$ up-regulation), specific changes in cells morphology and c-Myc or RET expression in LNCaP, U251, and TT human tumor lines (the latter - medullary thyroid carcinoma) [17].

Cancer cells induce special protective mechanisms, such as the heat shock protein mortalin synthesis [19], which inhibits MAPK expression and activation and thus protects cells from aging, growth arrest and apoptosis. Therefore, it is possible that, as is the case with MAPK $[5,16,17,19]$, thyroid tumor cells initiate special defense mechanisms that inhibit Akt activation and thus protect themselves against oncogene toxicity - senescence and cell cycle arrest. 
Another question that arises in the analysis of the obtained data is how a tumor cell replaces inactive Akt - one of the major protein kinases that control growth, energetics and cell division. The likely answer is contained in the works that suggest Akt replacement by other protein kinases in PI3K signaling pathway, including Sgk3 (serum/glucocorticoid regulated kinase) [20].

There is also the possibility of alternative Akt activation through Ser473 residue phosphorylation of mTORC2 and DNA-PK protein kinases complexes. However, it is known that such phosphorylation stimulates full Akt activity and, consequently, suppresses apoptosis by inhibiting FOXO proapoptotic protein family [21], which we have not observed in most thyroid tumors (Fig. 2). In addition, a number of protein kinases that are involved in oncogenesis, activate Akt, phosphorylating other amino acid residues of the kinase. Thus, Ack1 (TNK2) phosphorylates Tyr176 residue; Src and RTK6 - Tyr215, Tyr315 and Tyr326; TBK1 (TANK-binding kinase 1) Thr195, Ser378, Ser473 [22].

Thus, our findings indicate that Akt activity (by Thr308 phosphorylation) is not associated with thyroid tumor tissue proliferative processes. Apoptosis level, which was determined in the same tissues, does not correlate with the protein kinase activity either.

\section{АКТИВНІСТЬ ПРОТЁ̈НКІНАЗИ Akt У ПУХЛИНАХ ЩИТОПОДІБНОї ЗАЛОЗИ ЛЮДИНИ}

\section{Б. Б. Гуда, В. В. Пушкарьов, О. В. Журавель, В. М. Пушкарьов, А. С. Коваленко, Ю. М. Таращенко, М. Д. Тронько}

\section{ДУ «Інститут ендокринології та обміну речовин ім. В. П. Комісаренка НАМН України», Київ; e-mail: pushkarev.vm@gmail.com}

Вивчали експресію та активацію головної ефекторної протеїнкінази фофатидилінозитол-3кіназного каскаду (PI3K) - Акt в нормальних тканинах, доброякісних та високодиференційованих злоякісних (із метастазами та без) пухлинах щитоподібної залози людини. Спостерігали відмінності щодо вмісту Akt1 у пухлинній тканині порівняно з нормальними тканинами в папілярних карциномах та у тканині багатовузлового зобу. Експресія Akt як у пухлинах, так i в умовно нормальній тканині фолікулярної аденоми була вірогідно нижче, ніж у тканинах фолікулярної карциноми. Найнижчий рівень експресії Akt спостерігали в тканинах багатовузлового зобу. Сумарна активність всіх трьох ізоформ Akt1/2/3 була нижчою в пухлинах порівняно 3 нормальною тканиною. Таким чином, активність Akt (за фосфорилуванням Thr308) не пов'язана із проліферативними процесами в пухлинній тканині щитоподібної залози. Рівень апоптозу, який визначався в цих самих тканинах, також не корелює з активністю протеїнкінази. Обговорюються можливі механізми пригнічення активності сигнального каскаду PI3K/Akt у пухлинах щитоподібної залози.

К л ю ч о в і с с о в а: щитоподібна залоза, доброякісні та злоякісні пухлини, сигнальний каскад PI3K/Akt.

\section{АКТИВНОСТЬ ПРОТЕИНКИНАЗЫ Akt В ОПУХОЛЯХ ЩИТОВИДНОЙ ЖЕЛЕЗЫ ЧЕЛОВЕКА}
Б. Б. Гуда, В. В. Пушкарёв, Е. В. Журавель,
В. М. Пушкарёв, А. Е. Коваленко,
Ю. Н. Таращенко, Н. Д. Тронько

ГУ «Институт эндокринологии и обмена веществ им. В. П. Комиссаренко НАМН Украины», Киев; e-mail: pushkarev.vm@gmail.com

\begin{tabular}{llr}
\multicolumn{1}{c}{ Изучали экспрессию и } & активацию \\
главной эффекторной & протеинкиназы \\
фосфатидилинозитол-3-киназного & каскада
\end{tabular}
(РІ3К) - Акt в нормальных тканях, доброкачественных и высокодифференцированных злокачественных (с метастазами и без) опухолях щитовидной железы человека. Наблюдали различия в количестве Aktl в опухолевой ткани по сравнению с нормальными тканями в папиллярных карциномах и в ткани многоузлового зоба. Экспрессия Akt как в опухоли, так и в условно нормальной ткани фолликулярной аденомы была достоверно ниже, чем в тканях фолликулярной карциномы. Самый низкий уровень экспрессии Akt наблюдали в тканях многоузлового зоба. Суммарная активность всех трех изоформ $\mathrm{Akt1} / 2 / 3$ была ниже в опухолях по сравнению с нормальной тканью. Таким образом, активность Akt (по фосфорилированию Thr308) не связана с пролиферативными процессами в опухолевой ткани щитовидной железы. Уровень апоптоза, 
который определялся в этих же тканях, также не коррелирует с активностью протеинкиназы. Обсуждаются возможные механизмы подавления активности сигнального каскада PI3K/Akt в опухолях щитовидной железы.

К л ю ч е в ы е с л о в а: щитовидная железа, доброкачественные и злокачественные опухоли, сигнальный каскад PI3K/Akt.

\section{Reference}

1. Liu Q, Turner KM, Alfred Yung WK, Chen K, Zhang W. Role of AKT signaling in DNA repair and clinical response to cancer therapy. Neuro Oncol. 2014; 16(10): 1313-1323.

2. Kumar A, Rajendran V, Sethumadhavan R, Purohit R. AKT kinase pathway: a leading target in cancer research. Sci World J. 2013; 2013: 756134.

3. Xing M. Genetic alterations in the phosphatidylinositol-3 kinase/Akt pathway in thyroid cancer. Thyroid. 2010; 20(7): 697-706.

4. Pushkarev VV, Kovzun OI, Popadiuk ID, Pushkarev VM, Tronko MD. The role of the signal cascade Ras/PI3K/Akt in the formation of the resistance of thyroid anaplastic cancer cells to paclitaxel. Rep Nat Acad Sci Ukraine. 2011; (3): 169-171.

5. Guda BB, Pushkarev VM, Pushkarev VV, Kovalenko AYe, Taraschenko YM, Kovzun OI, Tronko MD. The expression and activation of extracellular signal-regulated kinase-1/2 and proliferating cell nuclear antigen content in normal tissue and human thyroid tumors. SM $J$ Endocrinol Metab. 2015; 1(1): 1002.

6. Zhang X, Tang N, Hadden TJ, Rishi AK. Akt, FoxO and regulation of apoptosis. Biochim Biophys Acta. 2011; 1813(11): 1978-1986.

7. Shimura T. Acquired radioresistance of cancer and the AKT/GSK3 $\beta /$ cyclin D1 overexpression cycle. J Radiat Res. 2011; 52(5): 539-544.

8. Wilks ST. Potential of overcoming resistance to HER2-targeted therapies through the PI3K/Akt/ mTOR pathway. Breast. 2015; 24(5): 548-555.

9. Xu Y, Li N, Xiang R, Sun P. Emerging roles of the p38 MAPK and PI3K/AKT/mTOR pathways in oncogene-induced senescence. Trends Biochem Sci. 2014; 39(6): 268-276.
10. Sin S, Kim SY, Kim SS. Chronic treatment with ginsenoside $\mathrm{Rg} 3$ induces Akt-dependent senescence in human glioma cells. Int J Oncol. 2012; 41(5): 1669-1674.

11. Wang CY, Kim HH, Hiroi Y, Sawada N, Salomone S, Benjamin LE, Walsh K, Moskowitz MA, Liao JK. Obesity increases vascular senescence and susceptibility to ischemic injury through chronic activation of Akt and mTOR. Sci Signal. 2009; 2(62): ral1.

12. Taylor JR, Lehmann BD, Chappell WH, Abrams SL, Steelman LS, McCubrey JA. Cooperative effects of Akt-1 and Raf- 1 on the induction of cellular senescence in doxorubicin or tamoxifen treated breast cancer cells. Oncotarget. 2011; 2(8): 610-626.

13. Ying $\mathrm{Y}$, Zhu $\mathrm{H}$, Liang Z, Ma X, Li S. GLP1 protects cardiomyocytes from palmitate-induced apoptosis via Akt/GSK3b/b-catenin pathway. $J$ Mol Endocrinol. 2015; 55(3): 245-262.

14. Toker A. Achieving specificity in Akt signaling in cancer. Adv Biol Regul. 2012; 52(1): 78-87. Review.

15. Park JI, Strock CJ, Ball DW, Nelkin BD. The Ras/Raf/MEK/extracellular signal-regulated kinase pathway induces autocrine-paracrine growth inhibition via the leukemia inhibitory factor/JAK/STAT pathway. Mol Cell Biol. 2003; 23(2): 543-554.

16. Mooi WJ, Peeper DS. Oncogene-induced cell senescence-halting on the road to cancer. $N$ Engl $J$ Med. 2006; 355(10): 1037-1046.

17. Hong SK, Yoon S, Moelling C, Arthan D, Park JI. Noncatalytic function of ERK1/2 can promote Raf/MEK/ERK-mediated growth arrest signaling. J Biol Chem. 2009; 284(48): 33006-33018.

18. Park JI. Growth arrest signaling of the Raf/MEK/ ERK pathway in cancer. Front Biol (Beijing). 2014; 9(2): 95-103.

19. Wu PK, Hong SK, Veeranki S, Karkhanis M, Starenki D, Plaza JA, Park JI. A mortalin/ HSPA9-mediated switch in tumor-suppressive signaling of Raf/MEK/extracellular signalregulated kinase. Mol Cell Biol. 2013; 33(20): 4051-4067. 
20. Bruhn MA, Pearson RB, Hannan RD, Sheppard KE. AKT-independent PI3-K signaling in cancer - emerging role for SGK3. Cancer Manag Res. 2013; 5: 281-292.

21. Hemmings BA, Restuccia DF. PI3K-PKB/Akt pathway. Cold Spring Harb Perspect Biol. 2012; 4(9): a011189.
22. Mahajan K, Mahajan NP. PI3K-independent AKT activation in cancers: a treasure trove for novel therapeutics. J Cell Physiol. 2012; 227(9): 3178-3184.

Received 14.07.2016 